JUURNAL

of Health Inequalities

\title{
Professor Martin McKee and his contribution to the development of public health research in Poland
}

\author{
Kinga Janik-Koncewicz \\ Institute - European Observatory of Health Inequalities, Calisia University, Kalisz, Poland
}

\begin{abstract}
ADDRESS FOR CORRESPONDENCE: Kinga Janik-Koncewicz, Institute - European Observatory of Health Inequalities, Calisia University, Nowy Świat 4, 62-800 Kalisz, Poland. e-mail:k.janik-koncewicz@akademiakaliska.edu.pl
\end{abstract}

I am very pleased to present the profile of Professor Martin McKee, his contribution to the development of public health research in Poland, and his collaboration with Polish scientists, including the editors of our Journal.

Martin McKee is Professor of European Public Health at London School of Hygiene and Tropical Medicine. He was trained in medicine in Northern Ireland, with postgraduate training in internal medicine and public health in London. For more information, please see Prof McKee's biographical note in the article The coronavirus pandemic: learning from international experience on pages: 80-83 [1].

Professor Martin McKee has led major public health research programmes in Europe for over two decades. For many years, he supported and fostered the work of numerous researchers studying the most pressing health challenges faced by countries of Central and Eastern Europe, including the impact of the social and economic transition in the region after the collapse of the Iron Curtain in 1989.

The beginning of Prof McKee's collaboration with the Polish scientific community dates back to late 1990s when together with Professor Zatoński he took part in the first programme, funded by the World Bank, aiming at closing the health gap between Eastern and Western Europe conducted under leadership of Professor Pekka Puska and Professor McKee, with the participation of leading European epidemiologists and public health experts. Following the project meeting in Budapest, Hungary, he published a review of the cardiovascular burden in Central and Eastern Europe [2]. The article described the potential factors shaping the divergent rates of cardiovascular diseases between Eastern and Western Europe. The authors pointed to, among others, tobacco smoking, dietary factors such as animal fat consumption, and alcohol intake, as the key reasons for the persisting differences between the regions.
Professor McKee's further contribution to the debate on the east-west health gap came in June 2000, when he participated in the $2^{\text {nd }}$ Conference on Health Status of Central and Eastern European Populations after transition, organised in Cancer Center and Institute of Oncology, Warsaw, Poland. This conference gathered leading European and global epidemiologists and researchers. Professor McKee was a key contributor to the strategic discussion on how to close the gap in access to health between Eastern and Western parts of Europe (Photo 1). Other prominent participants of the conference included Sir Richard Peto, Professor of Medical Statistics and Epidemiology at the University of Oxford and a leading expert on tobacco-related deaths, Professor Peter Boyle, who at the time was the Director of the Division of Epidemiology and Biostatistics at the European Institute of Oncology in Milan, Italy and who since 2004 headed the International Agency for Research on Cancer in Lyon, France, and Dr. Nigel Gray from the European Institute of Oncology in Milan and the International Agency for Cancer Research in Lyon, France (see Photo 2). This meeting marked the beginning of work that resulted in the publication of the seminal, European Commission-funded report HEM - Closing the gap [3]. The three-year project HEM - Closing the gap - Reducing premature mortality. Baseline for monitoring health evolution following enlargement (no 2003121) submitted within the framework of Public Health Program 20032008, DG Sanco, identified the causes of health differences between EU15 countries and the new Member States which accessed the EU in 2004.

In later years, Professor McKee was one of the contributors to the Prospective Urban and Rural Epidemiological study (PURE), in which Poland was one of the key participant countries. The PURE study explores the impact of a wide range risk factors on cardiovascular diseases, diabetes, lung diseases, cancers, kidney disease, 
brain health and injuries among hundreds of thousands of participants from more than 1,000 urban and rural communities in 27 countries around the world. For more information on the PURE Poland study please see the article Prospective urban and rural epidemiology Poland study design in previous issue of the Journal [4].

Another project building an understanding of health in Poland in which Professor McKee was involved was the epidemiological analysis of men's health in Europe commissioned by the European Commission. The analysis was led by a group of leading experts and constituted the first comprehensive appraisal of the health of men across the 27 member states of the European Union. The full report, The state of men's health in Europe. Extended report [5], can be found on the European Commission's website: (https://ec.europa.eu/health/sites/health/files/state/docs/ men_health_extended_en.pdf).

Professor McKee is also involved in fostering the next generation of Polish public health researchers. Together with Mateusz Zatoński, his Master's student at the London School of Hygiene and Tropical Medicine (LSHTM) in 2016 they published research on alcohol control policy in Poland [6]. Later, together with Professor Martin Gorsky, Prof McKee was Mateusz's PhD supervisor. Mateusz in 2019 completed his thesis entitled State, society, and the politics of smoking in Poland, during and after communism (1960-2000) [7], and received his doctoral degree from LSHTM. The full text of the thesis is stored on the website of the LSHTM Research Online Repository: https:// researchonline.lshtm.ac.uk/id/eprint/4653914/.

More recently, Prof. McKee has been collaborating with the Institute-European Observatory of Health Inequalities at Calisia University, Kalisz, Poland. In October 2020 he gave the inaugural lecture at Calisia University, entitled The coronavirus pandemic: learning from international experience, at the Inauguration Ceremony of the 2020/2021 Academic Year (see the transcript of the lecture in article on pages: 80-83) [1]. The transcript of the lecture was published in a Polish healthcare magazine "Health Manager" [8]. Together with scholars from Calisia University, in December 2020 Prof. McKee published an analysis of the problem of alcohol-related liver cirrhosis in Poland in The Lancet Gastroenterology and Hepatology [9]. Prof. McKee is currently collaborating with the Institute's associates on preparing a paper evaluating the regulatory interventions against the COVID-19 pandemic in Poland.

Since the launch of the first issue of the Journal of Health Inequalities, Prof. McKee has been a member of the Journal's editorial board.

\section{ACKNOWLEDGEMENTS}

KJK would like to thank Mateusz Zatoński for help with the English edition of the text. The photos used in the publication come from the archives of prof. Witold Zatoński and were used with his consent.

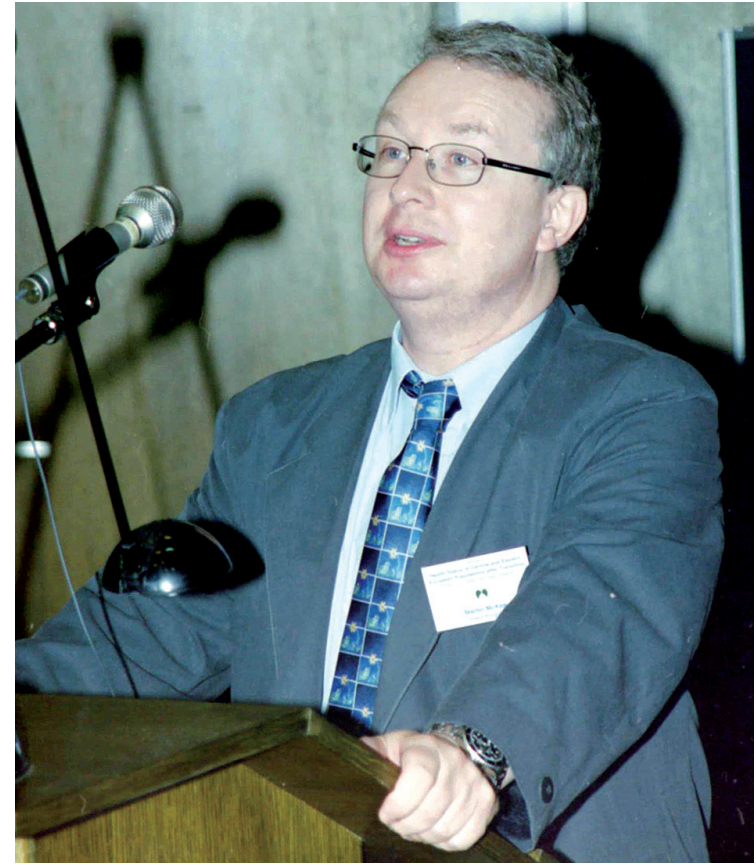

Pното 1. Professor Martin McKee delivering his lecture at the $2^{\text {nd }}$ Conference on Health Status of Central and Eastern European Populations after transition, 5-7 June 2000, Warsaw, Poland

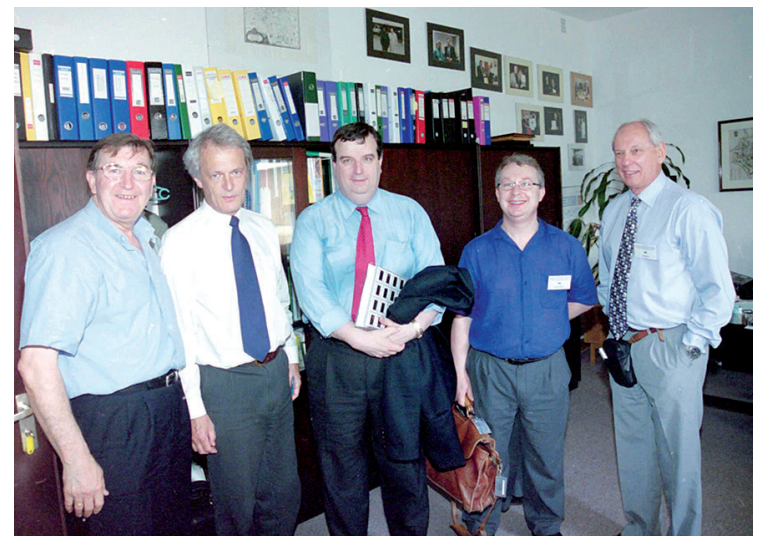

PHOTO 2. Among the participants of the $2^{\text {nd }}$ Conference on Health Status of Central and Eastern European Populations after transition, 5-7 June 2000, Warsaw, Poland, were, from the left side: prof. Witold Zatoński, prof. Richard Peto, prof. Peter Boyle, prof. Martin McKee, Dr. Nigel Gray

\section{DISCLOSURE}

The author reports no conflict of interest.

\section{References}

1. McKee M. The coronavirus pandemic: learning from international experience. J Health Inequal 2020; 6 (2): 80-83.

2. McKee M, Zatoński W. How the cardiovascular burden of illness is changing in eastern Europe. Evid Based Cardiovasc Med 1998; 2 (2): 39-41.

3. Zatoński $W$ and the HEM project team. Closing the health gap in European Union. The Maria Skłodowska-Curie Memorial Cancer Center and Institute of Oncology, Warsaw 2008. 
4. Zatońska K, Zatonski WA, Szuba A. Prospective urban and rural epidemiology Poland - study design. J Health Inequal 2016; 2 (2): 136-141.

5. White A, de Sousa B, de Visser R, et al. The state of men's health in Europe. Extended report. European Union, 2011. Available from: https://ec.europa.eu/health/sites/health/files/state/docs/ men_health_extended_en.pdf (accessed: 15 November 2020).

6. Zatoński M, Hawkins B, McKee M. Framing the policy debate over spirits excise tax in Poland. Health Promot Int 2018; 33 (3): 515-524.
7. Zatoński MZ. State, society, and the politics of smoking in Poland, during and after communism (1960-2000). PhD thesis. London School of Hygiene \& Tropical Medicine, London 2019.

8. McKee M. Martin McKee o międzynarodowych doświadczeniach z COVID-19 [Martin McKee on international experience with COVID-19]. Menedżer Zdrowia 2020; 9-10: 22-26.

9. Zatoński WA, Zatoński MZ, Janik-Koncewicz K, McKee M. Alcohol-related liver cirrhosis in Poland: the reservoir effect. Lancet Gastroenterol Hepatol 2020; 5 (12): 1035.

\section{JOINT PUBLICATIONS (IN CHRONOLOGICAL ORDER)}

1. Gilmore AB, Österberg E, Heloma A, Zatoński W, Delchava E, McKee M. Free trade versus protection of health: the examples of alcohol and tobacco. In: Health policy and European union enlargement. McKee M, MacLehose L, Nolte E (eds.). Open University Press, Maidenhead, England 2004: 198-224.

2. Zatoński W, Didkowska J. Closing the gap: cancer in Central and Eastern Europe. Chapter 13. In: Responding to the challenge of cancer in Europe. Coleman MP, Alexe D-M, Albreht T, McKee M (eds.). Institute of Public Health of the Republic of Slovenia, Ljubljana 2008: 253-278.

3. White A, de Sousa B, de Visser R, Hogston R, Aage S, Makara P, Richardson N, Zatoński W. The state of men's health in Europe. Extended report. European Union, 2011. Available from: https://ec.europa.eu/health/sites/health/files/state/docs/men_ health_extended_en.pdf (accessed: 15 November 2020).

4. White A, McKee M, Richardson N, de Visser R, Madsen SA, de Sousa BC, Hogston R, Zatoński W, Makara P. Europe's men need own health strategy. Br Med J 2011; 343: d7397.

5. White A, De Sousa B, De Visser R, Hogston R, Madsen SA, Makara P, McKee M, Raine G, Richardson N, Clarke N, Zatoński W. Men's health in Europe. JMH 2011; 8 (3): 192-201.

6. Chow CK, Teo KK, Rangarajan S, Islam S, Gupta R, Avezum A, Bahonar A, Chifamba J, Dagenais G, Diaz R, Kazmi K, Lanas F, Wei L, Lopez-Jaramillo P, Fanghong L, Ismail NH, Puoane T, Rosengren A, Szuba A, Temizhan A, Wielgosz A, Yusuf R, Yusufali A, McKee M, Liu L, Mony P, Yusuf S, PURE (Prospective Urban Rural Epidemiology) Study investigators: Zatoński W. Prevalence, awareness, treatment, and control of hypertension in rural and urban communities in high-, middle-, and low-income countries. JAMA 2013; 310 (9): 959-968.

7. Corsi DJ, Subramanian SV, Chow CK, McKee M, Chfamba J, Dagenais G, Diaz R, lqbal R, Kelishadi R, Kruger A, LAnas F, LopezJaramilo P, Mony P, Mohan V, Avezum A, Oguz A, Rahman MO, Rosengren A, Szuba A, Li W, Yusoff K, Yusufali A, Rangarajan S, Teo K, Yusuf S, PURE Study investigators: Zatoński W. Prospective Urban Rural Epidemiology (PURE) study: Baseline characteristics of the household sample and comparative analyses with national data in 17 countries. Am Heart J 2013; 166: 636-646.

8. White A, McKee M, de Sousa B, de Visser R, Hogston R, Madsen SA, Makara P, Richardson N, Zatoński W, Raine G. An examination of the association between premature mortality and life expectancy among men in Europe. Eur J Public Health 2014; 24 (4): 673-679.

9. Yusuf S, Rangarajan S, Teo K, Islam S, Li W, Liu L, Bo J, Lou Q, Lu F, Liu T, Yu L, Zhang S, Mony P, Swaminathan S, Mohan V, Gupta R, Kumar R, Vijayakumar K, Lear S, Anand S, Wielgosz A, Diaz R, Avezum A, Lopez-Jaramillo P, Lanas F, Yusoff K, Ismail N, labal R, Rahman O, Rosengren A, Yusufali A, Kelishadi R, Kruger A, Puoane T, Szuba A, Chifamba J, Oguz A, McQueen M, McKee M, Dagenais G. PURE Investigators. Cardiovascular risk and events in 17 low-, middle-, and high-income countries. N Engl J Med 2014; 371 (9): 818-827.

10. Smyth A, Teo KK, Rangarajan S, O'Donnell M, Zhang X, Rana P, Leong DP, Dagenais G, Seron P, Rosengren A, Schutte AE, Lopez-Jaramillo P, Oguz A, Chifamba J, Diaz R, Lear S, Avezum A, Kumar R, Mohan V, Szuba A, Wei L, Yang W, Jian B, McKee M, Yusuf S; PURE Investigators. Alcohol consumption and cardiovascular disease, cancer, injury, admission to hospital, and mortality: a prospective cohort study. Lancet 2015; 386 (10007): 1945-1954.

11. Khatib R, McKee M, Shannon H, Chow C, Rangarajan S, Teo K, Wei L, Mony P, Mohan V, Gupta R, Kumar R, Vijayakumar K, Lear SA, Diaz R, Avezum A, Lopez-Jaramillo P, Lanas F, Yusoff K, Ismail N, Kazmi K, Rahman O, Rosengren A, Monsef N, Kelishadi R, Kruger A, Puoane T, Szuba A, Chifamba J, Temizhan A, Dagenais G, Gafni A, Yusuf S; PURE study investigators. Availability and affordability of cardiovascular disease medicines and their effect on use in high-income, middle-income, and low-income countries: an analysis of the PURE study data. Lancet 2016; 387 (10013): 61-69.

12. Attaei MW, Khatib R, McKee M, Lear S, Dagenais G, Igumbor EU, AlHabib KF, Kaur M, Kruger L, Teo K, Lanas F, Yusoff K, Oguz A, Gupta R, Yusufali AM, Bahonar A, Kutty R, Rosengren A, Mohan V, Avezum A, Yusuf R, Szuba A, Rangarajan S, Chow C, Yusuf S; PURE study investigators (Zatoński WA). Availability and affordability of blood pressure-lowering medicines and the effect on blood pressure control in high-income, middle-income, and low-income countries: an analysis of the PURE study data. Lancet Public Health 2017; 2 (9): e411-e419. 